\title{
Reshaping healthcare delivery for elderly patients: the role of community paramedicine; a systematic review
}

Julia van Vuuren ${ }^{1 *} \mathbb{D}$, Brodie Thomas ${ }^{1}$, Gina Agarwal ${ }^{2,3}$, Sean MacDermott ${ }^{1}$, Leigh Kinsmann ${ }^{4}$, Peter O'Meara ${ }^{5}$ and Evelien Spelten ${ }^{1}$

\begin{abstract}
Background: Healthcare systems are overloaded and changing. In response to growing demands on the healthcare systems, new models of healthcare delivery are emerging. Community paramedicine is a novel approach in which paramedics use their knowledge and skills beyond emergency health response to contribute to preventative and rehabilitative health. In our systematic review, we aimed to identify evidence of the community paramedicine role in care delivery for elderly patients, with an additional focus on palliative care, and the possible impact of this role on the wider healthcare system.

Methods: A systematic review of peer-reviewed literature from MEDLINE, Embase, CINAHL, and Web of Sciences was undertaken to identify relevant full-text articles in English published until October 3, 2019. Additional inclusion criteria were studies focussing on extended care paramedics or community paramedics caring for elderly patients. Case studies were excluded. All papers were screened by at least two authors and underwent a quality assessment, using the Joanna Briggs Institute appraisal checklists for cross sectional, qualitative, cohort, and randomised controlled trial studies to assess the methodological quality of the articles. A process of narrative synthesis was used to summarise the data.

Results: Ten studies, across 13 articles, provided clear evidence that Community Paramedic programs had a positive impact on the health of patients and on the wider healthcare system. The role of a Community Paramedic was often a combination of four aspects: assessment, referral, education and communication. Limited evidence was available on the involvement of Community Paramedics in palliative and end-of-life care and in care delivery in residential aged care facilities. Observed challenges were a lack of additional training, and the need for proper integration and understanding of their role in the healthcare system.

(Continued on next page)
\end{abstract}

\footnotetext{
* Correspondence: j.vanvuuren@latrobe.edu.au

The abstract of this paper was presented as a poster at the Australasian College of Paramedicine 2020 International Conference (ACPIC20): van Vuuren J, Thomas B, Agarwal G, O'Meara P, Spelten E. Reshaping healthcare delivery for elderly patients: the role of Community Paramedicine. A systematic review. Poster presented at: Australasian College of Paramedicine 2020 International Conference; 2020 October 21-23; Online.

'Department of Community Health, Rural Health School, La Trobe University, Melbourne, Australia

Full list of author information is available at the end of the article
}

C C The Author(s). 2021 Open Access This article is licensed under a Creative Commons Attribution 4.0 International License, which permits use, sharing, adaptation, distribution and reproduction in any medium or format, as long as you give appropriate credit to the original author(s) and the source, provide a link to the Creative Commons licence, and indicate if changes were made. The images or other third party material in this article are included in the article's Creative Commons licence, unless indicated otherwise in a credit line to the material. If material is not included in the article's Creative Commons licence and your intended use is not permitted by statutory regulation or exceeds the permitted use, you will need to obtain permission directly from the copyright holder. To view a copy of this licence, visit http://creativecommons.org/licenses/by/4.0/ The Creative Commons Public Domain Dedication waiver (http://creativecommons.org/publicdomain/zero/1.0/) applies to the data made available in this article, unless otherwise stated in a credit line to the data. 


\begin{abstract}
(Continued from previous page)
Conclusions: The use of community paramedics in care delivery could be beneficial to both patients' health and the wider healthcare system. They already play a promising role in improving the care of our elderly population. With consistent adherence to the training curriculum and effective integration within the wider healthcare system, community paramedics have the potential to take on specialised roles in residential aged care facilities and palliative and end-of-life care.
\end{abstract}

Keywords: Community paramedicine, Emergency medical technicians, Palliative care, Nursing home, Elderly, Health services for the aged, Terminal care

\section{Background}

In response to growing demands on the healthcare systems, new models of healthcare delivery are emerging [1-4]. The healthcare workforce, jurisdictional authorities and healthcare organisations are becoming more differentiated and embracing inter-professional collaboration and task substitution. This growing international trend in healthcare policy refers to a shift away from historical workforce hierarchies, and to allocating roles based on professional accomplishment $[1,4]$. One of the areas currently undergoing rapid and significant change is delivery of care to elderly adults $[2,3]$.

It has been well established that the world's population is ageing [5]. Elderly adults experience more illnesses which are often chronic conditions, such as cancer, or cardiovascular diseases [6]. They typically have multiple diseases (such as dementia, osteoporosis and arthritis) and the severity score of comorbidity increases with age $[7,8]$, requiring more complex and specialised care. Therefore, the already high demand on palliative care (PC), end-of-life care (EOL) (together: PEOL), and (specialised) aged care is likely to increase in the near future [8]. This increased demand will occur alongside a predicted healthcare workforce shortage. This is likely to prove particularly challenging for Residential Aged Care Facilities (RACFs), where the number of visiting physicians is forecast to decrease [2].

Elderly adults residing in RACFs are a complex and vulnerable population, with high levels of frailty, functional impairment, and comorbidities including cognitive impairment [9]. The number of people in residential aged care is increasing in Western countries and there are concerns about the care provided. Harrington et al. found that in their study standards and levels of care in most countries do not meet levels recommended by experts [10]. In Australia, aged care services admissions increased by $42 \%$ in 2017-18 [11] and the current Royal Commission into Aged Care has concluded that aged care is failing to meet basic community expectations and quality of care [12]. Some of the issues highlighted include patchy and fragmented palliative care and difficulties in recruiting and retaining adequately skilled staff [12].
Elderly adults, including RACF residents, comprise a considerable percentage of all emergency department presentations and hospital admissions [13-16]. Residents of RACFs experience higher hospital admission rates than community-dwelling elderly adults [17]. Yet, it is debatable whether emergency department visits and hospitalisation always lead to improved health outcomes for this vulnerable group. Emergency departments have been identified as potentially harmful environments for the elderly, especially those with dementia $[3,18]$. Once admitted to hospital, elderly patients are more at risk of adverse events, such as delirium, functional decline, and readmission $[15,19]$.

Given the identified negative impact of hospitalisation on the elderly population, it has been suggested that ways to prevent ED presentation for non-urgent conditions, which might be better managed at place of residence, be explored [20,21]. Several models of healthcare service delivery are emerging that challenge traditional professional boundaries [2]. As ED presentations of the elderly often coincide with Paramedic Service transport, this patient population has been associated with increased delays for Paramedic Services and the ED, leading to negative consequences for both patients and the Paramedic Service system [22, 23]. Community paramedicine $(\mathrm{CPN})$ is a new approach aims to address this and other system shortfalls. In this extension of their scope of practice, paramedics use their knowledge and skills beyond emergency health response to introduce preventative and rehabilitative health. They are also involved in social programs as part of an integrated health-care effort, as well as treating minor conditions in the field or referring patients to non-ED health resources [24-27]. CPN has been proven to have favourable outcomes [25]. However, as the discipline is still evolving, consensus is lacking on what community paramedics (CPs) can contribute to the healthcare of elderly and within the wider healthcare system [25].

In light of this, CPN could potentially be further evolved to become an additional resource for RACFs through the provision of more specialised care, especially in palliative and end-of-life situations. The rapid expansion of paramedic practice has left the profession with 
developing professional and clinical boundaries, and current frameworks may no longer be consistent with actual practice or the expectations of healthcare consumers. Exploring new and emerging models of healthcare that align paramedicine with the changing landscape is essential to guide the advancement of this profession [28]. In this systematic review, we specifically focus on emerging models of healthcare for elderly patients. Our aim is to identify the best available evidence of the role CPN currently has in healthcare delivery for elderly patients and the impact that this might have on the wider healthcare system.

We addressed the following research questions:

1. What role does CPN currently have in healthcare delivery for elderly adults?

2. What is the impact that this healthcare delivery by $\mathrm{CPs}$ could have on patient health and the wider healthcare system?

3. Is there evidence to support CPN involvement in healthcare delivery in RACFs and PEOL care?

\section{Methods}

Data source and search strategy

A systematic review of the literature was conducted using the PRISMA reporting guidelines [29]. Because we aimed to uncover the international evidence for CPN, to confirm current practice, and identify and inform areas for future research, a systematic review was deemed more appropriate than a scoping review [30]. Due to funding related time constraints, we did not register a protocol with PROSPERO [31].

The aim was to identify evidence for the role that community paramedicine could have in the care delivery for elderly people. MEDLINE, Embase, CINAHL, and Web of Sciences were searched to identify all relevant full-text articles in English published until October 3, 2019. The search terms covered the following areas, using MeSH terms and text words: (1) emergency medical services, including ambulance and paramedic; (2) palliative and end-of-life care; (3) aged care, including nursing homes and health services for the aged; and (4) terms related to community paramedicine. The search strategy is available in a supplementary file (see Additional file 1). To ensure the widest possible search, no date filter was used. During the course of the search, references citied in systematic reviews were screened for potential further references.

\section{Inclusion and exclusion criteria}

The inclusion and exclusion criteria are shown in Table 1. Studies that looked at paramedics in the traditional emergency role without further training were deemed not relevant as the differentiating factor for the $\mathrm{CP}$ role is working beyond the traditional scope with additional training. We included studies with elderly patient populations, palliative care patients, and RACF patients. In order to not exclude relevant studies, study designs could include randomised controlled trials, pre-

Table 1 Inclusion and exclusion criteria

\begin{tabular}{|c|c|c|}
\hline Criteria & Inclusion & Exclusion \\
\hline Language & English language & Non-English \\
\hline Article type & Peer-reviewed & $\begin{array}{l}\text { Abstract } \\
\text { Poster } \\
\text { Editorial } \\
\text { Letter } \\
\text { Chapter }\end{array}$ \\
\hline $\begin{array}{l}\text { Type of } \\
\text { studies }\end{array}$ & $\begin{array}{l}\text { Intervention Studies } \\
\text { Quantitative and qualitative studies } \\
\text { Randomized control studies }\end{array}$ & Case Studies \\
\hline $\begin{array}{l}\text { Patient } \\
\text { Problem }\end{array}$ & $\begin{array}{l}\text { Elderly patients } \\
\text { Palliative or end-of-life care patients } \\
\text { Residential aged care facility residents }\end{array}$ & $\begin{array}{l}\text { Studies of children, adolescents, young } \\
\text { adults. }\end{array}$ \\
\hline Intervention & $\begin{array}{l}\text { Interventions focussing on paramedics with extended skills/community paramedics caring } \\
\text { for elderly patients. }\end{array}$ & $\begin{array}{l}\text { Interventions focussing on paramedics } \\
\text { solely as transport role. } \\
\text { Interventions focussing on community } \\
\text { paramedicine for children. } \\
\text { Intervention focusses on community } \\
\text { paramedic training. }\end{array}$ \\
\hline Control & $\mathrm{N} / \mathrm{A}$ & $\mathrm{N} / \mathrm{A}$ \\
\hline Outcome & $\begin{array}{l}\text { The role of community paramedicine }(C P) \text { in care delivery for elderly adults } \\
\text { Impact of CP on health care system } \\
\text { Impact of CP on patient health } \\
\text { The role of CP in Residential Aged Care Facilities and Palliative and End-of-Life care }\end{array}$ & N/A \\
\hline
\end{tabular}


post designs, cross-sectional, cohort, and qualitative studies.

\section{Critical appraisal}

The Joanna Briggs Institute (JBI) appraisal checklists for cross sectional, qualitative, cohort, and randomised controlled trial studies were used to assess the methodological quality of the articles [32].

The authors looked for strengths and weaknesses in each article by answering 'Yes', 'No', 'Unclear', or 'Not Applicable' to each question. For this quality assessment, a numerical value of one was attached to each 'Yes' answer, and the 'Not Applicable' answers were not included. The number of 'Yes' answers was then divided by the total number of applicable questions of the checklist. Studies with a score of $70 \%$ or more were considered to be at low risk of bias [33-35]. As the aim of this study is to inform practice with the best available evidence, 70\% was chosen as the threshold for inclusion, which was agreed upon prior to the commencement of the critical appraisal, as recommended by the JBI reviewer's manual [36].

\section{Data extraction and analysis}

One author (JV) extracted the data in line with a piloted form looking at study characteristics and main findings. The first round of data extraction summarised the study characteristics, these included year, country, patient population, role or task of the paramedic, and the paramedic's extra training. The second round focussed on study participants, aim of the study and the main findings.

JV undertook the first round of identifying emerging themes. Each paper was viewed through the prism of the role of $\mathrm{CP}$ and a process of narrative synthesis was used to summarise the current state of knowledge and understanding [37], identifying the role of CP in the studies and the impact they had on the health care system. A narrative synthesis approach has been used elsewhere in health services research [38], and is well suited to examining questions looking at effectiveness or cost effectiveness, appropriateness, or feasibility of implementation of interventions. It also suits a research question that dictates the inclusion of a wide range of research designs, producing qualitative and quantitative findings [37], which was deemed appropriate for this review as we did not exclude articles based on research methodology.

In an iterative process, two other authors (BT, ES) independently reviewed the data and adjusted the summarised themes by expanding or merging themes and subheadings. Finally, all authors reached an agreement on the main themes.

\section{Results}

\section{Search outcomes}

The literature search identified exactly 1700 records (Fig. 1). Citations were screened using Covidence [39], which is a web-based software platform that streamlines and supports the process of systematic reviews. Six hundred duplicates were identified. The title and abstract of the remaining 1100 papers were screened by two reviewers independently. All authors acted as reviewers at each stage of the screening process. Articles were excluded according to the criteria summarised in Table 1 . For full-text screening, 84 papers were retrieved, which were read in detail by two reviewers independently and the exclusion and inclusion criteria were applied (Table 1). A further 59 were excluded, resulting in 25 studies being critically appraised. The quality assessment was undertaken independently by authors JV and BT, and no overall disagreement was found. Twelve articles did not meet the criteria and were excluded from the review [40] (see Additional file 2).

\section{Study characteristics}

A total of ten studies, which were reported across 13 articles (Table 2), were included in the systematic review, $[26,41-52]$. The majority of the studies were conducted in Canada (6), and the rest in the USA (3) and the UK (1). All of the studies focussed on a senior or elderly population. The participant sample size varied across the studies with the larger studies ranging between 1092 and 4081 participants, and the smaller qualitative studies between 21 and 94. The participants were a mix of elderly patients, family members, community members, and healthcare workers The studies used a mix of methods, with five qualitative studies, three cross sectional studies, three randomised controlled trials, and two cohort studies.

\section{The role of the community paramedic}

In regard to the care delivery for elderly adults, all studies, with the exception of one [52], described different aspects of the role of the $\mathrm{CP}$ (Table 2). The roles varied somewhat across the studies. Four main themes emerged: assessment, referral, education, and communication.

\section{Assessment}

Most studies reported on assessment as part of the role of the CP $[26,41-45,47-50]$. The evaluations were conducted in the patient's home or one-on-one in the building where they lived. In some studies, the evaluation focussed on whether the patient should be transferred to ED or the treatment of acute illnesses could be completed at home [41, 42, 48-51]. Here, the aim was to prevent unnecessary ED transports and visits, and 


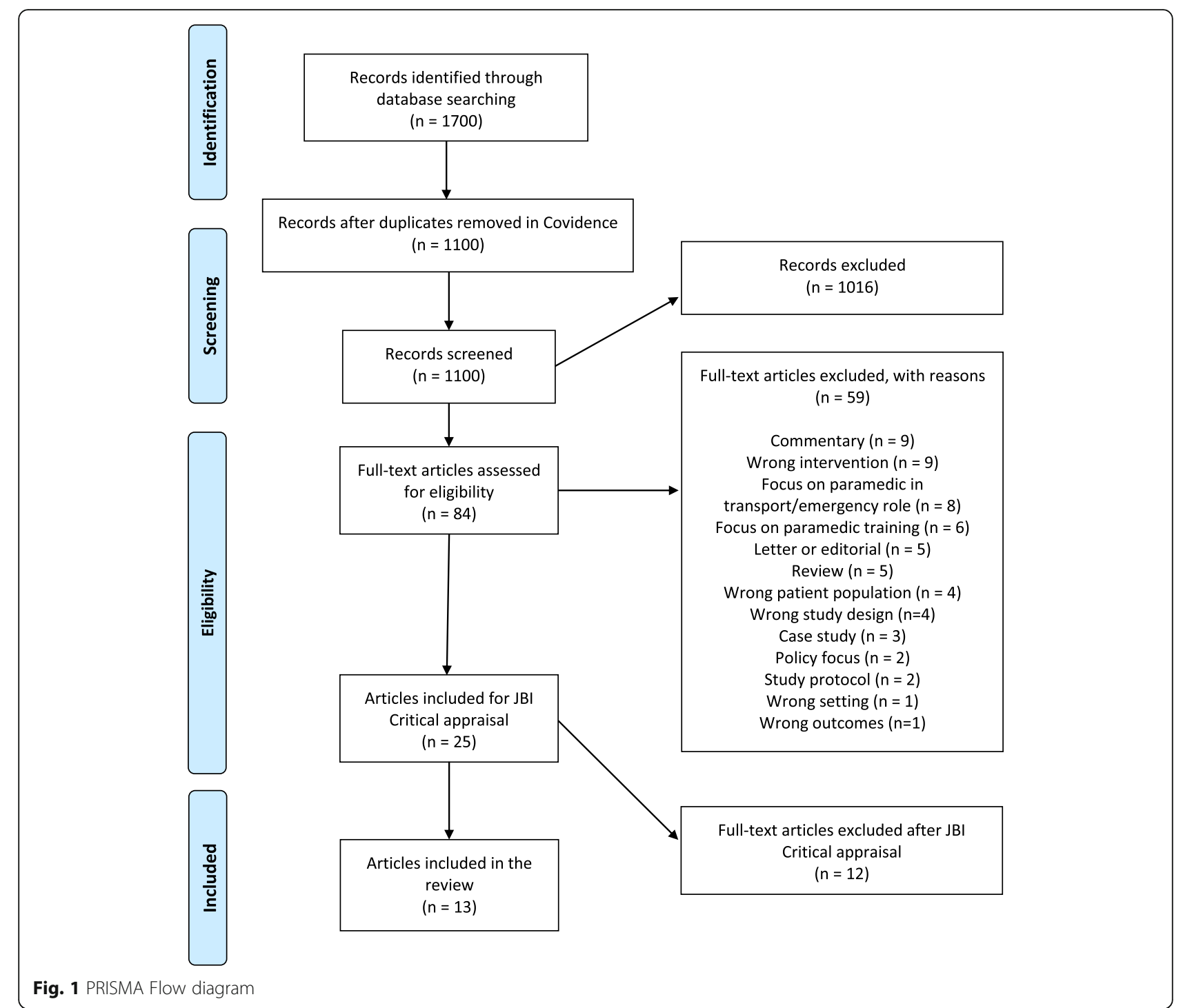

hospital admissions. Other studies reported a preventative risk assessment, aiming to identify high-risk patients and to provide education or referral where needed [26, $43-45,47,48]$. The most common risks tested for were cardiovascular, diabetes, weight checks, and fall risks. Bennett et al. also included post-discharge follow-up assessments as well as home safety assessments as part of the role of the paramedic [45].

\section{Referral}

The next most commonly identified aspect of the paramedics' role was referral. Based on the identification of high-risk patients, CPs would ensure targeted referral to community resources, community services, or to specific primary healthcare workers [26, 43-47, 49, 51]. Most studies that provided risk assessments, also provided referral to urgent care or ED in case of an emergency medical incident. One study reported that the use of
CPs allowed for transfers at a time where the receiving department could see the patient more quickly [49].

\section{Education}

Within the studies focussing on preventative risk assessment, education was another important preventative tool $[26,43-45,47]$. Studies encompassing an education component included those focussing on general disease prevention and health information sessions [43, 44], as well as studies which provided specific education and information on local resources based on the patient's level of risk $[26,47]$.

\section{Communication}

The last aspect of the role of a CP was communication. This was generally described as regular communication of the patient's health information with their family physician [26, 43, 44, 47]. In one study, the CP 
Table 2 Study, patient and role of paramedic characteristics

\begin{tabular}{|c|c|c|c|c|c|c|}
\hline & $\begin{array}{l}\text { Author(s) } \\
\text { Year }\end{array}$ & Country & Study Design & Patient characteristics & Role of Paramedic & $\begin{array}{l}\text { Paramedic's additional } \\
\text { training }\end{array}$ \\
\hline 1 & $\begin{array}{l}\text { Abrashkin } \\
\text { et al. } 2016 \\
\text { [41] } \\
\text { Abraskhin } \\
\text { et al. } 2019 \\
\text { [42] }\end{array}$ & USA & $\begin{array}{l}\text { Observational } \\
\text { studies }\end{array}$ & $\begin{array}{l}\text { Elderly patients, home-bound with } \\
\text { two or more chronic condition, en- } \\
\text { rolled in the advanced illness man- } \\
\text { agement (AIM) program. }\end{array}$ & $\begin{array}{l}\text { Assessment } \\
\text { - In-home evaluation and } \\
\text { treatment of acute illnesses. } \\
\text { - Telephone triage with acuity } \\
\text { rating code } \\
\text { Communication } \\
\text { - Discussion of emergency } \\
\text { department (ED) transport or } \\
\text { attempted home } \\
\text { interventions with physician } \\
\text { through video or telephone } \\
\text { conferencing. }\end{array}$ & $\begin{array}{l}\text { Additional } 40 \mathrm{~h} \text { of instruction in } \\
\text { geriatrics and home-based pri- } \\
\text { mary care through didactic train- } \\
\text { ing and physician observation. }\end{array}$ \\
\hline 2 & $\begin{array}{l}\text { Agarwal } \\
\text { et al. } 2018 \\
\text { [43] } \\
\text { Agarwal } \\
\text { et al. } 2019 \\
\text { [44] }\end{array}$ & Canada & $\begin{array}{l}\text { Cluster } \\
\text { randomized } \\
\text { controlled trials }\end{array}$ & $\begin{array}{l}\text { Residents aged } 55 \text { years and older } \\
\text { of a subsidized apartment } \\
\text { building. }\end{array}$ & $\begin{array}{l}\text { Assessment } \\
\text { - Assessment of } \\
\text { cardiovascular, diabetes, and } \\
\text { fall risk. } \\
\text { Education } \\
\text { - Disease prevention and } \\
\text { health promotion sessions. } \\
\text { Referral } \\
\text { - Identification of high-risk pa- } \\
\text { tients and referral to } \\
\text { healthcare } \\
\text { - Targeted referral to } \\
\text { community resources } \\
\text { - Referral to urgent care or ED } \\
\text { in case of emergency medical } \\
\text { incident. } \\
\text { Communication } \\
\text { - Regular communication of } \\
\text { participants' health } \\
\text { information with their family } \\
\text { physician. }\end{array}$ & $\begin{array}{l}\text { Community paramedics (CP) } \\
\text { undertook online modules on } \\
\text { chronic diseases, their risk } \\
\text { factors, risk assessment using } \\
\text { validated tools, and health } \\
\text { promotion methods } \\
\text { (approximately } 4 \mathrm{~h} \text { of training); } \\
\text { webinars were used for } \\
\text { CP@clinic database training ( } 1 \mathrm{~h} \\
\text { of training); in-person observa- } \\
\text { tion using a train-the-trainer } \\
\text { model was expected by each } \\
\text { paramedic service for at least } 1 \\
\text { clinic session of } 2-3 \mathrm{~h} \text { duration. }\end{array}$ \\
\hline 3 & $\begin{array}{l}\text { Bennett } \\
\text { et al. } 2018 \\
{[45]}\end{array}$ & USA & $\begin{array}{l}\text { Pre/post-test } \\
\text { with a } \\
\text { comparison } \\
\text { group study } \\
\text { design. }\end{array}$ & $\begin{array}{l}\text { Frequent users of the ED and have } \\
\text { at least } 1 \text { chronic disease. }\end{array}$ & $\begin{array}{l}\text { Assessment } \\
\text { - Home safety assessments } \\
\text { - General assessments: } \\
\text { medication reconciliation, } \\
\text { blood glucose, and weight } \\
\text { checks } \\
\text { - Cardiovascular and } \\
\text { respiratory care } \\
\text { - Post-discharge follow-up } \\
\text { Education } \\
\text { - Patient education } \\
\text { Referral } \\
\text { - Connecting participants to } \\
\text { resources for primary care } \\
\text { delivery } \\
\text { - Applications for benefits } \\
\text { - Referral to urgent care or ED } \\
\text { in case of emergency medical } \\
\text { incident. }\end{array}$ & $\begin{array}{l}200 \mathrm{~h} \text { didactic training } \& 100 \mathrm{~h} \\
\text { local clinic time, with at least } 10 \\
\text { years in Paramedic Services and } \\
\text { at least } 4 \text { years at the local } \\
\text { county Paramedic Services. }\end{array}$ \\
\hline 4 & $\begin{array}{l}\text { Brydges } \\
\text { et al. } 2015 \\
{[46]}\end{array}$ & Canada & $\begin{array}{l}\text { Interpretivist } \\
\text { qualitative } \\
\text { approach }\end{array}$ & Seniors & $\begin{array}{l}\text { Referral } \\
\cdot \text { - Initiating referrals to } \\
\text { community services }\end{array}$ & $\begin{array}{l}\text { Varied forms of education: } \\
\text { training by continuing medical } \\
\text { education, email } \\
\text { communication, or none at all. }\end{array}$ \\
\hline 5 & $\begin{array}{l}\text { Brydges } \\
\text { et al. } 2016 \\
\text { [26] } \\
\text { Agarwal } \\
\text { et al. } 2017 \\
{[47]}\end{array}$ & Canada & $\begin{array}{l}\text { Brydges: } \\
\text { Interpretivist } \\
\text { qualitative } \\
\text { approach } \\
\text { Agarwal: A } \\
\text { prospective } \\
\text { pre-post ap- } \\
\text { proach for } \\
\text { intervention }\end{array}$ & $\begin{array}{l}\text { Residents aged } 55 \text { years and older } \\
\text { living in a subsidized housing } \\
\text { building }\end{array}$ & $\begin{array}{l}\text { Assessment } \\
\text { - Two four-hour sessions per } \\
\text { week. } \\
\text { - Cardiovascular, diabetes and } \\
\text { fall risk assessment. } \\
\text { Education } \\
\text { - Providing education based } \\
\text { on risk assessment, including } \\
\text { information on local }\end{array}$ & $\begin{array}{l}\text { Half-day long training session by } \\
\text { public health nurse and family } \\
\text { doctor in taking blood pressure, } \\
\text { conducting health assessment, } \\
\text { educating residents and using } \\
\text { the program's database. }\end{array}$ \\
\hline
\end{tabular}


Table 2 Study, patient and role of paramedic characteristics (Continued)

\begin{tabular}{|c|c|c|c|c|c|c|}
\hline & $\begin{array}{l}\text { Author(s) } \\
\text { Year }\end{array}$ & Country & Study Design & Patient characteristics & Role of Paramedic & $\begin{array}{l}\text { Paramedic's additional } \\
\text { training }\end{array}$ \\
\hline & & & study & & $\begin{array}{l}\text { resources. } \\
\text { Referral } \\
\text { - Developed individualised } \\
\text { action plan directing } \\
\text { participants to available } \\
\text { community resources. } \\
\text { - Standard protocol was } \\
\text { followed for emergency } \\
\text { action. } \\
\text { Communication } \\
\text { - Participant's information was } \\
\text { faxed to family physician } \\
\text { once a month. }\end{array}$ & \\
\hline 6 & $\begin{array}{l}\text { Dainty } \\
\text { et al. } 2018 \\
\text { [48] }\end{array}$ & Canada & $\begin{array}{l}\text { Qualitative } \\
\text { study }\end{array}$ & $\begin{array}{l}\text { Patients living with one of three } \\
\text { major chronic diseases: diabetes } \\
\text { mellitus, congestive heart failure, } \\
\text { and chronic obstructive pulmonary } \\
\text { disease. }\end{array}$ & $\begin{array}{l}\text { Assessment } \\
\text { - Scheduled home visits at 3- } \\
\text { month intervals and follow- } \\
\text { up and emergency home } \\
\text { visits to assess and treat } \\
\text { patients. }\end{array}$ & $\begin{array}{l}\text { Six-week intensive course in } \\
\text { chronic disease management. }\end{array}$ \\
\hline 7 & $\begin{array}{l}\text { Jensen } \\
\text { et al. } 2014 \\
\text { [49] }\end{array}$ & Canada & $\begin{array}{l}\text { Qualitative } \\
\text { approach }\end{array}$ & LTC residents & $\begin{array}{l}\text { Assessment } \\
\text { - Managing acute situations in } \\
\text { the patient's home } \\
\text { environment. } \\
\text { Referral } \\
\text { - Arranging transfers to occur } \\
\text { at a time where the receiving } \\
\text { department can see the } \\
\text { patient more quickly. }\end{array}$ & $\begin{array}{l}\text { Two weeks of additional training } \\
\text { in: (1) geriatric assessments and } \\
\text { management; (2) EOL care; ( } 3 \text { ) } \\
\text { primary wound closure } \\
\text { techniques (suturing, tissue } \\
\text { adhesive); and (4) point of care } \\
\text { testing. }\end{array}$ \\
\hline 8 & $\begin{array}{l}\text { Kant et al. } \\
2018[50]\end{array}$ & USA & $\begin{array}{l}\text { Case series / } \\
\text { Mixed methods }\end{array}$ & Geriatric patients & $\begin{array}{l}\text { Assessment } \\
\cdot \text { Home-based episodic care }\end{array}$ & - \\
\hline 9 & $\begin{array}{l}\text { Mason } \\
\text { et al. } 2008 \\
\text { [51] }\end{array}$ & UK & $\begin{array}{l}\text { Cluster- } \\
\text { randomized } \\
\text { controlled trial }\end{array}$ & $\begin{array}{l}\text { Patients aged } 60 \text { years or older } \\
\text { with minor injury or illness. }\end{array}$ & $\begin{array}{l}\text { Assessment } \\
\text { - Assess and, where possible, } \\
\text { treat patients in the } \\
\text { community. } \\
\text { Referral } \\
\text { - Referral to ED, general } \\
\text { practitioner, district nurse, or } \\
\text { community social services. }\end{array}$ & $\begin{array}{l}\text { Three-week lecture-based pro- } \\
\text { gram to assess and (where pos- } \\
\text { sible) treat older people in the } \\
\text { community, followed by } 45 \text { of } \\
\text { supervised practice. }\end{array}$ \\
\hline 10 & $\begin{array}{l}\text { O'Meara } \\
\text { et al. } 2015 \\
{[27]}\end{array}$ & Canada & $\begin{array}{l}\text { Observational, } \\
\text { ethnographic } \\
\text { research }\end{array}$ & - & - & $\begin{array}{l}\text { Enhanced knowledge and } \\
\text { broader understanding of health } \\
\text { issues. }\end{array}$ \\
\hline
\end{tabular}

communicated with a physician to discuss ED transport or in-home treatment [41, 42].

\section{Additional training}

The observation that the role of the paramedic varied across the studies might be related to the lack of additional training that were reported throughout the studies reviewed (Table 2). Training ranged anywhere from half a day [26, 47] to a six-week intensive course [48]. Training varied in duration as well as content. Abrashkin et al. stated that their additional training included $40 \mathrm{~h}$ of instruction in geriatrics and home-based primary care through didactic training and physician observation [41, 42]. Agarwal et al. included online modules on chronic diseases and risk factors combined with webinars and in-person observation $[43,44]$. Jensen et al. concluded that "soft skills" and the ability to handle difficult conversations were essential for a $\mathrm{CP}$ and that current education and training was inadequate [49].

\section{The impact on care}

Our second research question aimed to investigate how a CP working in care delivery for elderly patients might have impact on both the patient's health and the wider healthcare system. The findings for each study can be found in Table 3 with overall findings and potential challenges discussed in detail below (Table 3 ).

\section{The patient's health}

Several studies reported improved patient health outcomes [26, 43-48, 50]. Prevalent risk factors assessed by the CPs were weight, cardiovascular, diabetes, and fall risks. One study reported that $15 \%$ of patients experienced a drop in risk category for their diabetes after 6 to 
Table 3 Impact of the community paramedic role in the care of the elderly on patient health and the wider healthcare system

\begin{tabular}{|c|c|c|c|c|}
\hline & Author(s) & $\begin{array}{l}\text { Study } \\
\text { participants }\end{array}$ & Aims / Outcome Measures & Main findings/themes \\
\hline 1 & $\begin{array}{l}\text { Abrashkin } \\
2016[41] \\
\text { Abrashkin } \\
2019[42]\end{array}$ & $\begin{array}{l}\text { Patients } \\
2016 \\
(n=1602) \\
\text { Median age: } \\
83 \text { years } \\
\text { Had at least one } \\
\text { emergency } \\
\text { response }(n=773) \\
\text { Used CP at least } \\
\text { once ( } n=404) \\
\text { Used only } \\
\text { traditional } \\
\text { Paramedic } \\
\text { Services ( } n=369) \\
2019 \\
(n=1159) \\
\text { Average age: } 86 \\
\text { years }\end{array}$ & $\begin{array}{l}\text { - Emergency Department (ED) transport and } \\
\text { hospitalisation rate after Community Paramedic (CP) } \\
\text { visit. } \\
\text { - Response time, time on scene and medications } \\
\text { administered. } \\
\text { - Post-visit feedback } \\
\text { - Patient/caregiver satisfaction } \\
\text { - Descriptive data }\end{array}$ & $\begin{array}{l}\text { Healthcare system } \\
\text { • In } 78 \% \text { of CP responses, individuals were } \\
\text { evaluated, treated, and remained at home. } \\
\text { - One or more treatments were administered in } \\
27.6 \% \text { of CP responses. } \\
\text { - After transport to ED, hospital admission rates } \\
\text { were significantly higher for individuals transported } \\
\text { after a CP response than a traditional Paramedic } \\
\text { Services' response. } \\
\text { - Only } 1.7 \% \text { of patient who received a CP visit and } \\
\text { were not transported to ED, were subsequently } \\
\text { seen in an ED within } 24 \mathrm{~h} \text { of response. } \\
\text { - Transport rates were not significantly different for } \\
\text { those with ACP or without. } \\
\text { Patient health } \\
\text { - Individuals seen by CP were older, have more } \\
\text { activity of daily living (ADL) dependencies, and } \\
\text { have a do-not-resuscitate order than those using } \\
\text { only traditional Paramedic Services' responses. } \\
\text { - Both groups had high rates of advance care } \\
\text { planning. } \\
\text { - High acuity responses were the most common. } \\
\text { Patient satisfaction } \\
\text { - Patient/caregiver satisfaction was high, stating that } \\
\text { they felt that the goals of care were accounted for } \\
\text { and they would use CP in future medical } \\
\text { emergency. } \\
\text { General } \\
\text { - CP program can provide a safe and effective } \\
\text { option for responding to and treating frail older } \\
\text { adults in their home, avoiding transport to ED and } \\
\text { likely hospitalisation. }\end{array}$ \\
\hline 2 & $\begin{array}{l}\text { Agarwal } \\
2018[43] \\
\text { Agarwal } \\
2019[44]\end{array}$ & $\begin{array}{l}\text { Patients } \\
2018 \\
\text { Intervention ( } n= \\
455) \\
\text { Control ( } n=637) \\
2019 \\
\text { Intervention ( } n= \\
2009) \\
\text { Control } \\
(n=2072) \\
\text { Both groups: } \\
\text { Mean age of } 70 \\
\text { yrs }\end{array}$ & $\begin{array}{l}\text { - Monthly ambulance calls at the building level per } 100 \\
\text { apartment units. } \\
\text { - Secondary health, knowledge, behaviour outcomes } \\
\text { (individual level), including changes in risk factors. } \\
\text { - Changes in blood pressure (BP), lifestyle risk-factor } \\
\text { measures, health-related quality-of-life (HRQoL), and } \\
\text { quality-adjusted-life-years (QALYS). }\end{array}$ & $\begin{array}{l}\text { Healthcare system } \\
\text { - There were significantly less calls in the } \\
\text { intervention buildings. } \\
\text { Patient health } \\
\text { - The intervention improved risk factor profiles and } \\
\text { the health-related quality of life of the participants. } \\
\text { - Three HRQoL domains (self-care, usual activities, } \\
\text { pain, and discomfort) and overall QALY significantly } \\
\text { improved among the intervention group. } \\
\text { - The intervention participants had improved CANR } \\
\text { ISK, implying the intervention had an impact in } \\
\text { reducing the participants' risk of developing } \\
\text { diabetes. } \\
\text { - The intervention participants' blood pressures } \\
\text { showed a significant and sustained decrease. }\end{array}$ \\
\hline 3 & $\begin{array}{l}\text { Bennett } \\
2018[45]\end{array}$ & $\begin{array}{l}\text { Patients } \\
\text { Intervention } \\
(n=68) \\
\text { Average age } 57.6 \\
\text { yrs. } \\
\text { Control }(n=125) \\
\text { Average age } 55.4 \\
\text { yrs }\end{array}$ & $\begin{array}{l}\text { - Satisfaction of participants } \\
\text { - Screening and compliance rates } \\
\text { - Appropriate use of care } \\
\text { - (Non-emergent) calls to Paramedic Services } \\
\text { - Time spent on scene } \\
\text { - Time to return to services } \\
\text { - ED visits } \\
\text { - Inpatient admissions } \\
\text { - } 30 \text {-day readmission rate } \\
\text { - Costs }\end{array}$ & $\begin{array}{l}\text { Healthcare system } \\
\text { - The program was cost-effective. } \\
\text { - Within healthcare utilisation, care was moved from } \\
\text { ED and inpatient to outpatient and medical home- } \\
\text { based: significantly less transports and less ED visits. } \\
\text { Patient health } \\
\text { - Patients experienced an improved level of care } \\
\text { and improved outcomes. } \\
\text { Patient satisfaction } \\
\text { - The patients were satisfied with the service. }\end{array}$ \\
\hline 4 & $\begin{array}{l}\text { Brydges } \\
2015 \text { [46] }\end{array}$ & $\begin{array}{l}\text { Paramedics } \\
(n=23)\end{array}$ & $\begin{array}{l}\text { Get a better understanding of the ways in which } \\
\text { paramedics experience and participate in community- } \\
\text { based referral programs }\end{array}$ & $\begin{array}{l}\text { Integration } \\
\text { - The referral program confronted the paramedic } \\
\text { with an alternative approach to patient care which } \\
\text { is in conflict with the traditional values and beliefs } \\
\text { grounded in emergency response. } \\
\text { - Participants felt that they had an inadequate } \\
\text { knowledge base on the referral programs, due to } \\
\text { inadequate education. } \\
\text { - Feedback from the services following a referral, }\end{array}$ \\
\hline
\end{tabular}


Table 3 Impact of the community paramedic role in the care of the elderly on patient health and the wider healthcare system (Continued)

$\begin{array}{llll}\text { Author(s) } & \begin{array}{l}\text { Study } \\ \text { participants }\end{array} & \text { Aims / Outcome Measures } & \text { Main findings/themes }\end{array}$

5 Brydges

2016 [26]

Agarwal

2017 [47]

Patients

$(n=15)$

2017

$(n=79)$

Mean age $72.2 \mathrm{yrs}$
Changes in:

- Number of emergency Paramedic Services calls

from the seniors' residence building

- Mean blood pressure of participants

- Diabetes risk profile

To understand the patients' experience with the community paramedicine program.
6 Dainty 2018 [48]

\section{Patients}

$(n=30)$

Age 42-95

Family members

$(n=10)$
To understand the experiences and perspectives of patients and families involved with the Expanding Paramedicine in the Community (EPIC)
7 Jensen 2014 [49]
Healthcare workers $(n=21)$
To better understand the experience of those directly and professionally involved in various aspects of the extended care paramedics (ECP).

\section{Kant 2018 Patients} [50] $\quad(n=35)$
To understand the use and potential impact of a community paramedicine program on patient care, provided to the paramedics, was seen as inadequate.

- Participants felt that they, the employer and sometimes even the CCAC were not held accountable by the program.

- Participants saw the referral program as a way that they could step into the role of patient advocates.

Healthcare system

- The number of emergency calls dropped by $7.1 \%$ after 6 months, and by $25 \%$ after 12 months.

- The program could decrease healthcare costs.

Patient health

- Prevalent risk factors assessed by the CP were: high waist circumference and elevated body mass index, and stress.

- Systolic and diastolic BP dropped by the 3rd and 5th CP visit respectively.

- $15 \%$ of patients dropped in risk category for diabetes after 6 to 12 months.

Patient satisfaction

- The paramedics were seen as caring, respectful and trustful healthcare providers. The sessions were an individualised experience.

- Paramedics had a dual role as both health advocates and as emergency experts.

- Patient felt that it was reassuring knowing someone was taking care of them.

Patient health

- Patients indicated they learned new health information in management of their disease. Patient satisfaction

- Participants developed a unique relationship with the EPIC paramedics, which they saw as important, trusted, and essential members of their healthcare. - Paramedics were seen as exceeding their expectations and went 'beyond the call of duty' to take care of the patients.

- EPIC recognised the patients' and provided a safety net in times of exacerbation and was a source of health education and accountability.

Training

- The ECPs current training was seen as inadequate.

- "Soft skills" and the ability to handle difficult

conversations were seen as an essential for an ECP.

- ECPs saw decision making as a significant element of their role and reported longer time on the call as they discuss the situation with staff and/or family.

Integration

- The ECPs are able to bridge communication with the physician or family, and effective communication was seen as important to build relationships with $\mathrm{LTC}$ staff.

End-of-Life (EOL)

- There was a mixed view on how frequent people thought ECPs are involved in EOL care. - Multiple participants saw the ECP role as permitting enough flexibility to pause and determine what the best option is for an $\mathrm{EOL}$ patient.

- Advanced care directives were seen as useful, but they can also be confusing.

Healthcare system

- The majority of patients could be treated at home 
Table 3 Impact of the community paramedic role in the care of the elderly on patient health and the wider healthcare system (Continued)

\begin{tabular}{|c|c|c|c|c|}
\hline & Author(s) & $\begin{array}{l}\text { Study } \\
\text { participants }\end{array}$ & Aims / Outcome Measures & Main findings/themes \\
\hline & & $\begin{array}{l}\text { Mean age } 87.8 \\
\text { Geriatric primary } \\
\text { care team } \\
(n=10)\end{array}$ & including understanding provider perspectives. & $\begin{array}{l}\text { and did not require higher levels of care } \\
\text { - Potential reduction of unnecessary ED visits/ } \\
\text { hospitalisations, decreasing the risk of hospital } \\
\text { acquired complications. } \\
\text { Patient health } \\
\text { - The program was seen as beneficial as it gave } \\
\text { patients greater access to care and provided } \\
\text { reassurance and relief for caregivers. } \\
\text { Integration } \\
\text { - Health workers felt that they were notified too } \\
\text { late about their patients regarding acute issues or } \\
\text { general documentation. But the CP visit notes did } \\
\text { give them a better insight into the patients' home } \\
\text { and social situation. } \\
\text { - Geriatric team members expressed concern } \\
\text { regarding the ability of CPs to provide appropriate } \\
\text { geriatric-focussed care. They also questioned the in- } \\
\text { tegration of the program with primary care and } \\
\text { whether the patients with acute needs should con- } \\
\text { tact the service or their primary care provider first. } \\
\text { They did see the role of CP as first responder more } \\
\text { clearly in on-call situations. } \\
\text { - The program is unique in that it uses a nurse } \\
\text { practitioner or physician assistant as well as a CP. }\end{array}$ \\
\hline 9 & $\begin{array}{l}\text { Mason } \\
2008 \text { [51] }\end{array}$ & $\begin{array}{l}\text { Patients } \\
\text { Intervention }(n= \\
1118) \\
\text { Control }(n=907)\end{array}$ & $\begin{array}{l}\text { To evaluate the safety of the clinical decisions made } \\
\text { and appropriateness } \\
\text { of care provided by the Paramedic Practitioners working } \\
\text { within the new service. This was measured by } \\
\text { unplanned ED attendance within } 7 \text { days of paramedic } \\
\text { visit. }\end{array}$ & $\begin{array}{l}\text { Healthcare system } \\
\text { - There was an overall } 10.8 \% \text { return visit rate at the } \\
\text { ED within } 7 \text { days. } \\
\text { - There were more returns visits in the intervention } \\
\text { group, but the proportion returning with a related } \\
\text { condition in both groups was not found } \\
\text { significantly different. } \\
\text { Patient health } \\
\text { - There was also no difference in mortality at } 28 \\
\text { days. } \\
\text { - The paramedics in this trial are assessing and } \\
\text { treating older people in a manner that is as safe as } \\
\text { the standard care provided by Paramedic Services } \\
\text { and ED. } \\
\text { - Suboptimal care was judged by either or both ED } \\
\text { clinician in } 2.1 \% \text { of the patients not admitted after } \\
\text { their index episodes, but this was not significantly } \\
\text { different between the groups. }\end{array}$ \\
\hline 10 & $\begin{array}{l}\text { O'Meara } \\
2015 \text { [27] }\end{array}$ & $\begin{array}{l}\text { A range of } \\
\text { participants: } \\
\text { - paramedic } \\
\text { service } \\
\text { managers } \\
\text { - paramedics } \\
\text { - educators } \\
\text { - physicians } \\
\text { - nurses } \\
\text { - other health } \\
\text { professionals } \\
\text { - patients } \\
\text { - community } \\
\text { members }\end{array}$ & $\begin{array}{l}\text { Identify and describe the nature of the relationship } \\
\text { between public engagement and the integration of CP } \\
\text { with local health, aged care, and social services. }\end{array}$ & $\begin{array}{l}\text { Engagement } \\
\text { - The program used a range of engagement } \\
\text { strategies to plan and implement key elements of } \\
\text { their program. } \\
\text { - The program developed elements of inclusiveness } \\
\text { thorough community paramedic interactions with } \\
\text { clients, families and carers in public and home } \\
\text { settings. } \\
\text { Integration } \\
\text { - Participants recognised the important role of the } \\
\text { program in integrating different services for } \\
\text { patients and helping them navigate through the } \\
\text { health, aged care and social service systems. } \\
\text { - It was not always obvious to some participants } \\
\text { how the CP program is integrated with the local } \\
\text { health system. } \\
\text { - It was noted that the longer-term sustainability of } \\
\text { the CP program is reliant on strong integration with } \\
\text { existing services. } \\
\text { - The program played a variety of roles. }\end{array}$ \\
\hline
\end{tabular}


12 months [26, 47], and similar results were seen in the study completed by Agarwal et al. [43, 44]. Mason et al. reported no difference in mortality between patients seen by CPs or Paramedic Services [51]. Additionally, two studies reported reduced patient blood pressures in association with a CPN program [26, 43, 44, 47]. Patients in these studies experienced improved levels of care and personal health [26, 43-45, 47], learned new health information to manage their disease [48], and the CPN programs gave the patients greater access to care, and provided reassurance and relief for caregivers [50].

\section{Patient satisfaction}

Patient satisfaction was reported as being high [26, 41, $42,45,47,48]$. Patients felt that the goals of care were accounted for and they would use the CPs in future medical emergencies $[41,42]$. The paramedics were seen as caring, respectful and trustworthy healthcare providers [26, 47, 48]. Patients felt it was reassuring to know someone was taking care of them [26, 47]; the paramedics were seen as going 'beyond the call of duty' to take care of patients [48].

\section{The wider healthcare system}

The majority of studies saw a reduction in emergency calls, transport to ED, ED visits, or hospitalisation [26, $41-45,47,50]$. Abrashkin et al. reported that in $78 \%$ of the CPs' responses, the individuals were evaluated, treated, and remained at home $[41,42]$. They found that if the patient did have to be transported, hospital admission rates were significantly higher for individuals transported after a CP response than a traditional Paramedic Services' response, indicating the CPs ability to identify the sickest individuals who need and want inpatient treatment. Another study reported that the number of emergency calls dropped by $25 \%$ after 12 months [26, 47]. Mason et al. investigated the safety of the clinical decisions made by the CPs through unplanned ED attendance within 7 days of the visit. They concluded that the CPs provided care at least as safe as the standard care provided by the Paramedic Services and the ED. The programs were also seen as a potential way to decrease healthcare costs $[26,45,47]$. The CPN programs were seen as a safe and effective option for responding and treating older adults at home [41, 42] and reducing the strain on Paramedic Services and ED by moving care from ED and inpatient to outpatient and medical homebased care [45].

\section{Integration}

As CPN is a new shift in the way this workforce is used, integration was seen as a challenge in some studies [46, $50,52]$. The referral program evaluated by Brydges et al. confronted the paramedic with an alternative approach to patient care which is in conflict with the traditional values and beliefs grounded in emergency response [46]. Another study described this confusion in the traditional emergency role versus a more primary care role in terms of where the CPN program would sit [50]. O'Meara et al. noted that their participating healthcare workers were not always clear on how the CPN program was integrated in the local health system. They did however recognise that the $\mathrm{CPN}$ program could play a key role in integrating different services and in helping patients navigate through the healthcare system [52]. They further noted that the CPN program currently plays a variety of roles within the healthcare system and that the long-term sustainability of the program is reliant on strong integration with existing services [52].

Communication between the $\mathrm{CPs}$ and other services could be improved according to some studies $[46,50]$. It was, however, noted that the information provided by the CPN program was useful in providing a better insight into the patient's home and social situation [50]. Jensen et al. found that the CPs were able to bridge the communication gap between the physician and family, and effective communication was seen as important to the building of relationships with Long Term Care (LTC) staff [49]. The CPs in this study collaborated with the physician and LTC staff in decision making and in the follow-up care [49].

\section{Residential aged-care facilities and palliative and end-of- life care}

Our systematic review found limited high-quality evidence to support CPN involvement in the care delivery in RACFs and PEOL care specifically, although there was high quality evidence for the role of CPN in care of elderly patients. Jensen et al. reported on a paramedic involvement in EOL in a long-term care facility [49]. The paramedics in this study managed acute situations in the patient's home environment and arranged transfers where necessary. They received extra training in geriatric assessment as well as EOL care. The other healthcare workers involved thought that the paramedics' current education and training was inadequate, but they were good in bridging communication between the different parties involved. The participants in this study had mixed views on how frequently CPs were involved in EOL care. They did, however, see the role as offering flexibility to pause and determine the best options for the EOL patient. Advanced care directives were seen as useful in terms of guiding the care of the patient, although some participants emphasised that they could be confusing as the wording used was not always clear to the CPs.

Two other studies were conducted in senior subsidized housing buildings with residents aged 55 and over [26, 
$43,44,47]$. The role of the community paramedic was preventative and entailed weekly drop-in sessions assessing and promoting health. Both studies reported positive impact on patient health and the wider health system. Although these studies did not take place within an RACF, a similar model might work within an RACF.

\section{Discussion}

\section{Main findings}

In this systematic review we aimed to identify evidence of the $\mathrm{CP}$ role in care delivery for elderly patients, with an additional focus on palliative care, and the impact that this new role might have on the wider healthcare system. All studies included fulfilled the JBI critical appraisal criteria, with most scoring high on the criteria. In terms of care delivery for elderly adults, the role of a $\mathrm{CP}$ was often a combination of four aspects: assessment, referral, education and communication. Additional training in the studies varied considerably, and there was no evidence of the international curriculum for CPN being used [53]. The studies provided clear evidence that the programs had a positive impact on the health of the patient, had high patient satisfaction, and could reduce the stress on other parts of the healthcare system. How CPN programs are integrated and varied from the traditional emergency role of a paramedic was seen as a challenge. Good integration is important to ensure long-term sustainability. Limited evidence was available on CPN involvement in care delivery in RACFs and PEOL care but the evidence to utilise CPs in the care delivery for elderly adults is promising.

\section{Interpretation of findings Role of paramedic}

The role of the $\mathrm{CP}$ varied across the studies, which is not surprising given that the concept is still evolving. This might also be linked to the finding that the training varied across the studies, and that the studies showed no evidence of using the international curriculum as a guide to additional training for CPN [53]. An additional explanation could be that the studies focussed on different areas of care, and therefore the training was aligned with the healthcare area. The four identified aspects (assessment, referral, education and communication) all seem important in delivery of care for elderly adults. To ensure consistency and safe care delivery and longer-term sustainability, adherence to the international curriculum is important. Simpson et al. found that paramedics experience confusion over their role and that this has a substantial impact on the decision-making process when caring for older fallers [54]. In their study of fallers, they concluded that education and training play a part in the decision-making as well as the paramedic's attitude toward patients [54]. Thus, more uniformity in training and improved role clarity could have a positive impact on providing patient-centred, good quality care to the elderly population.

Although the issue of how education and training might impact on outcomes was not one of our primary aims, it would be of interest if the identified programs were to be more widely implemented. Most of the included studies were from the US or Canada, which explains that the entry-to-practice education on death and dying for paramedics was lacking, as well as the reliance on short courses to upskill participants. In contrast, in Australia and the UK paramedics are educated in universities alongside other health professionals, with all health professional programs sharing content. In Australia it has been identified that paramedic education in the area of death and dying (including palliative care) could be enhanced [55].

Paramedicine as a profession has a unique position in the community and healthcare system. Paramedics have high autonomy in their work and they have a role in establishing or maintaining the trust from the community [28]. These characteristics support a shift beyond an exclusively emergency role. Such a shift, however, requires the profession to re-think how it is defined, which might cause tension with the more traditional views of paramedic practice. Until the new potential roles are fully understood and tested, these tensions may persist [28]. The CSA Group in Canada has developed a clear definition of a $\mathrm{CP}$ :

"A community paramedic is defined as a paramedic who has completed a formal and recognized educational program and has demonstrated competence in the provision of health education, clinical assessment and monitoring, point-of-care diagnostics, and treatment modalities within or beyond the role of traditional emergency care and transport." (p.13) [56]

They add to this that the goal of any CPN program should be to "promote the patient's access to the right care, delivered by the right provider, at the right time, resulting in the best outcomes and the most effective and efficient use of resources. The foundation of any program will be dependent on stable and sustainable partnerships among numerous community-based agencies, teams and organizations." (p.10) [57]. Therefore, it is recommended to adhere to the above definition and goals to ensure consistency in CPN programs.

\section{Reconfiguring healthcare workforce}

As mentioned earlier, there is a universal shift in the way the healthcare workforce is utilised, due to shortfalls in workforce supply or distribution. The workforce has 
diversified with for example specialised roles for nurses and other health professionals, of which CPN is an example. De Bont et al. categorised the development of new extended roles into two groups: (i) specialised roles which occupy a narrowly defined area of expertise, (ii) generic roles, which have a broader scope and cover a larger part of the care pathway. They concluded that the extended roles develop new ways of health service provision that suit healthcare organisations, encouraging and shaping organisation-oriented healthcare delivery [1].

A challenge to the integration of $\mathrm{CPN}$ programs is that the extended scope of practice may be classified as both a specialised and a generic role. As the CPs, especially in the care delivery for elderly adults, receive specific additional geriatric, risk assessment, or PEOL training, the role has developed according to the increasing complex needs of the elderly population. However, the $\mathrm{CP}$ also takes on a role of health advocate, educator, and point of reference between community health services, physicians, and hospitals, covering a larger part of the care pathway. The profession continues to be seen by other healthcare professionals as being exclusively as an emergency health profession. Moreover, good integration within the healthcare system is key to ensuring the longterm sustainability of any CPN program.

\section{RACF and PEOL care opportunities}

Our review found limited evidence for the involvement of CPs in the care delivery in RACFs and PEOL care. However, two studies were conducted in subsidized building for seniors, where the CPs had weekly sessions during which they checked for health risks and provided health promotion and education to residents $[26,43,44$, 47]. This setting is similar to a setting in an RACF, suggesting that a similar model might work in RACFs. As RACFs residents are an especially complex and vulnerable population, with high levels of frailty, functional impairment, and comorbidities including cognitive impairment, regular preventative and check-in health sessions might improve the health of these patients and provide access to quick emergency transport if necessary. One study in our review found that the CPs were effective in bridging the communication gap between the patients, family and physicians, as well as the RACF staff. They could potentially play a central role in improving and maintaining the health of residents in RACFs.

In PEOL care, many different healthcare professionals are involved, resulting sometimes in fragmented care. Another issue is the large discrepancy in numbers between those who wish to die at home and those that actually do so. A recent report on the sustainability of community PEOL care services, found that workforce shortages, along with pain medication and symptom management are key aspects that need to be addressed if patients' wishes in regard to place of care and place of death are to be addressed [58]. CPN could potentially play a role in symptom management and fill workforce gaps, whilst being a central communicator to ensure less fragmented care. The one study in our review that addressed EOL, found that the CPs had inadequate education and training, even though they did have the flexibility and time to make correct decisions for the patients [49].

The role CPN could have in RACFs and PEOL warrants further research, as the role could be a promising initiative to improve the health and specialised care for the older community.

\section{Implication for research and practice}

This review provides evidence to show that CPN involvement in the care delivery of elderly adults is increasing with positive results both for the population and the healthcare system. Based on the limited evidence available, this review has found that CPs could potentially provide the specialised care needed in these areas, whilst simultaneously reducing the pressure on hospitals and other healthcare providers.

\section{Limitations and strengths}

Since CPN is a developing concept, there is limited high-quality evidence available. Out of the potential 25 studies, only 13 satisfied the JBI critical appraisal criteria. However, the majority of the 13 studies included in this review scored highly on the JBI critical appraisal benchmark.

Another limitation of this review is that it could be argued that it is challenging to compare outcomes, due the variation in $\mathrm{CP}$ training across the studies. Nevertheless, the quality of each study was high, and the outcomes were consistently positive. This, in turn, facilitated the identification of overarching themes.

We see the results of the different studies as a strength. The shift to utilising CPs is promising on a number of levels, from patient health to the wider healthcare system. Our review is one of the few to summarise the evidence available in the evolving practice of CPs.

\section{Conclusions}

The healthcare system is often overloaded and ever changing. With workforce issues, rather than focussing on more healthcare workers, there is a growing international trend to develop new models of healthcare delivery to address the demand. With an ageing population, the demand on care delivery for elderly adults is inevitably increasing. The use of CPs in the care delivery could be beneficial to both patients' health and 
the wider healthcare system. CPs already play a promising role in improving the care of our elderly population. With consistent adherence to the training curriculum and effective integration within the wider healthcare system, CPs have the potential to take on specialised roles in RACFs and PEOL care.

\section{Supplementary Information}

The online version contains supplementary material available at https://doi. org/10.1186/s12913-020-06037-0.

Additional file 1. Database Search Strategy - Overview of applied search strategy across the databases.

Additional file 2. JBI Critical appraisal - Overview of critical appraisal results of the 25 studies.

\section{Abbreviations}

CP: Community Paramedic; CPN: Community paramedicine; PC: Palliative care; EOL: End-of-life; PEOL: Palliative and end-of-life care; RACF: Residential aged care facility; ED: Emergency department; JBI: Joanna Briggs Institute

\section{Acknowledgments}

We thank Ange Johns-Hayden, La Trobe University Librarian, for her support with conducting the literature search.

\section{Authors' contributions}

$\mathrm{J}, \mathrm{BT}$, and ES have contributed to the design of the work, screening of the search results, analysis and interpretation of the data, have drafted and revised the work. JV and BT undertook the critical appraisal. GA, SM, LK, and $P O$ have contributed to the screening of the search results and have revised the work. All authors have approved the submitted version and have agreed both to be personally accountable for the author's own contribution and to ensure that questions related to the accuracy or integrity of the any part of the work, even ones in which the author was not personally involved, are appropriately investigated, resolved, and the resolution documented in the literature.

\section{Funding}

La Trobe University provided a grant for international collaboration RFA Grant 2000004174. This review was part of the grant proposal. The University was not involved in the design of the study and collection, analysis, and interpretation of data nor in writing the manuscript.

\section{Availability of data and materials}

All data generated or analysed during this study are included in this published article and its supplementary information files.

\section{Ethics approval and consent to participate}

Not applicable.

\section{Consent for publication}

Not applicable.

\section{Competing interests}

The authors declare that they have no competing interests.

\section{Author details}

${ }^{1}$ Department of Community Health, Rural Health School, La Trobe University, Melbourne, Australia. ²Department of Family Medicine, McMaster University, Hamilton, Canada. ${ }^{3}$ Department of Health Research Methods, Evidence, and Impact, McMaster University, Hamilton, Canada. ${ }^{4}$ University of Newcastle and Mid-North Coast Local Health District, Port Macquarie Base Hospital, Port Macquarie, Australia. ${ }^{5}$ Department of Paramedicine, Monash University, Peninsula Campus, Melbourne, Australia.
Received: 17 May 2020 Accepted: 21 December 2020

Published online: 06 January 2021

\section{References}

1. de Bont A, van Exel J, Coretti S, Ökem ZG, Janssen M, Hope KL, et al. Reconfiguring health workforce: a case-based comparative study explaining the increasingly diverse professional roles in Europe. BMC Health Serv Res. 2016;16(1):637.

2. Dwyer T, Craswell A, Rossi D, Holzberger D. Evaluation of an aged care nurse practitioner service: quality of care within a residential aged care facility hospital avoidance service. BMC Health Serv Res. 2017;17(1):33.

3. Giebel C, Harvey D, Akpan A, Chamberlain P. Reducing hospital admissions in older care home residents: a 4-year evaluation of the care home innovation Programme (CHIP). BMC Health Serv Res. 2020;20(1):1-7.

4. Martin GP, Currie G, Finn R. Reconfiguring or reproducing intra-professional boundaries? Specialist expertise, generalist knowledge and the 'modernization' of the medical workforce. Soc Sci Med. 2009;68(7):1191-8.

5. United Nations. World population ageing 2017 - highlights. New York: Department of Economic and Social Affairs PD; 2017. Report no.: ST/ESA/ SER.A/39.

6. Australian Institute of Health and Welfare. Australia's health 2018. Canberra: Australian Government; 2018

7. Piccirillo JF, Vlahiotis A, Barrett LB, Flood KL, Spitznagel EL, Steyerberg EW. The changing prevalence of comorbidity across the age spectrum. Crit Rev Oncol Hematol. 2008;67(2):124-32.

8. World Health Organisation. Palliative care for older people: best practices. Copenhagen: World Health Organisation; 2011.

9. Rockwood K, Abeysundera MJ, Mitnitski A. How should we grade frailty in nursing home patients? J Am Med Dir Assoc. 2007;8(9):595-603.

10. Harrington C, Choiniere J, Goldmann M, Jacobsen FF, Lloyd L, McGregor M, et al. Nursing home staffing standards and staffing levels in six countries. J Nurs Scholarsh. 2012;44(1):88-98.

11. Australian Institute of Health and Welfare. GEN fact sheet 2017-18: admissions into aged care. Canberra: Australian Government; 2019.

12. Tracey $R$, Briggs $L$. Royal commission into aged care quality and safety: interim report: neglect. Canberra: The Royal Commission into Aged Care Quality and Safety; 2019

13. Australian Institute of Health and Welfare. Older Australia at a glance. Canberra: Australian Government; 2018.

14. Barker WH, Zimmer JG, Hall WJ, Ruff BC, Freundlich CB, Eggert GM. Rates, patterns, causes, and costs of hospitalization of nursing home residents: a population-based study. Am J Public Health. 1994;84(10):1615-20.

15. Crilly J, Chaboyer W, Wallis M, Thalib L, Green D. Predictive outcomes for older people who present to the emergency department. Australas Emerg Nurs J. 2008;11(4):178-83.

16. Mion LC, Palmer RM, Anetzberger GJ, Meldon SW. Establishing a casefinding and referral system for at-risk older individuals in the emergency department setting: the SIGNET model. J Am Geriatr Soc. 2001;49(10):137986.

17. Graverholt B, Riise T, Jamtvedt G, Ranhoff AH, Krüger K, Nortvedt MW. Acute hospital admissions among nursing home residents: a population-based observational study. BMC Health Serv Res. 2011;11(1):126.

18. Parke B, Hunter KF, Strain LA, Marck PB, Waugh EH, McClelland AJ. Facilitators and barriers to safe emergency department transitions for community dwelling older people with dementia and their caregivers: a social ecological study. Int J Nurs Stud. 2013;50(9):1206-18.

19. Ackroyd-Stolarz S, Guernsey JR, MacKinnon NJ, Kovacs G. Impact of adverse events on hospital disposition in community-dwelling seniors admitted to acute care. Healthc Q (Toronto, Ont). 2009:34-9. https://doi.org/10.12927/ hcq.2009.20964.

20. Gulacti U, Lok U, Celik M, Aktas N, Polat H. The ED use and non-urgent visits of elderly patients. Turk J Emerg Med. 2016;16(4):141-5.

21. Briggs R, Coughlan T, Collins R, O'Neill D, Kennelly SP. Nursing home residents attending the emergency department: clinical characteristics and outcomes. QJM. 2013;106(9):803-8.

22. Cone DC, Middleton PM, Marashi Pour S. Analysis and impact of delays in ambulance to emergency department handovers. Emerg Med Australas. 2012;24(5):525-33.

23. Kingswell C, Shaban RZ, Crilly J. Concepts, antecedents and consequences of ambulance ramping in the emergency department: a scoping review. Australas Emerg Nurs J. 2017;20(4):153-60. 
24. Agarwal G, Angeles RN, McDonough B, McLeod B, Marzanek F, Pirrie M, et al. Development of a community health and wellness pilot in a subsidised seniors' apartment building in Hamilton, Ontario: Community Health Awareness Program delivered by Emergency Medical Services (CHAP-EMS). BMC Res Notes. 2015;8(1):113.

25. Bigham BL, Kennedy SM, Drennan I, Morrison LJ. Expanding paramedic scope of practice in the community: a systematic review of the literature. Prehosp Emerg Care. 2013;17(3):361-72.

26. Brydges M, Denton M, Agarwal G. The CHAP-EMS health promotion program: a qualitative study on participants' views of the role of paramedics. BMC Health Serv Res. 2016;16(1):435.

27. O'Meara P, Stirling C, Ruest M, Martin A. Community paramedicine model of care: an observational, ethnographic case study. BMC Health Serv Res. 2015; 16(1):39.

28. Tavares W, Bowles R, Donelon B. Informing a Canadian paramedic profile: framing concepts, roles and crosscutting themes. BMC Health Serv Res. 2016;16(1):477

29. Moher D, Liberati A, Tetzlaff J, Altman DG, Group P. Preferred reporting items for systematic reviews and meta-analyses: the PRISMA statement. PLoS Med. 2009;6(7):e1000097.

30. Munn Z, Peters MD, Stern C, Tufanaru C, McArthur A, Aromataris E. Systematic review or scoping review? Guidance for authors when choosing between a systematic or scoping review approach. BMC Med Res Methodol. 2018;18(1):143.

31. Moher D, Tetzlaff J, Tricco AC, Sampson M, Altman DG. Epidemiology and reporting characteristics of systematic reviews. PLoS Med. 2007;4(3):e78.

32. Moola S, Munn Z, Tufanaru C, Aromataris E, Sears K, Sfetcu R, et al. Joanna Briggs Institute reviewer's manual: The Joanna Briggs Institute; 2017. Available from: https://reviewersmanual.joannabriggs.org/.

33. Goplen CM, Verbeek W, Kang SH, Jones CA, Voaklander DC, Churchill TA, et al. Preoperative opioid use is associated with worse patient outcomes after total joint arthroplasty: a systematic review and meta-analysis. BMC Musculoskelet Disord. 2019;20(1):234.

34. Melo G, Dutra KL, Rodrigues Filho R, Ortega AOL, Porporatti AL, Dick B, et al. Association between psychotropic medications and presence of sleep bruxism: a systematic review. J Oral Rehabil. 2018:45(7):545-54.

35. De Rezende HA, Melleiro MM, Shimoda GT. Interventions to reduce patient identification errors in the hospital setting: a systematic review protocol. JBI Evid Synth. 2019;17(1):37-42.

36. Briggs TIJ. Joanna Briggs Institute reviewers' manual. Adelaide: Joanna Briggs Institute; 2014.

37. Popay J, Roberts H, Sowden A, Petticrew M, Arai L, Rodgers M, et al. Guidance on the conduct of narrative synthesis in systematic reviews. In: A product from the ESRC methods programme version, vol. 1; 2006. p. b92.

38. Pretorius A, Karunaratne N, Fehring S. Australian physiotherapy workforce at a glance: a narrative review. Aust Health Rev. 2016;40(4):438-42.

39. Veritas Health Innovation. Covidence systematic review software. Melbourne: Veritas Health Innovation; 2018.

40. Hannes K. Critical appraisal of qualitative research. In: Noyes J, Booth A, Hannes K, Harden A, Harris J, Lewin S, et al., editors. Supplementary guidance for inclusion of qualitative research in cochrane systematic reviews of interventions cochrane collaboration qualitative methods group; 2011.

41. Abrashkin K, Washko J, Zhang J, Poku A, Kim H, Smith K. Providing acute care at home: community paramedics enhance an advanced illness management program-preliminary data. J Am Geriatr Soc. 2016;64(12): 2572-6.

42. Abrashkin K, Poku A, Ramjit A, Washko J, Zhang J, Guttenberg M, et al. Community paramedics treat high acuity conditions in the home: a prospective observational study. BMJ Support Palliat Care. 2019:bmjspcare2018-001746. https://doi.org/10.1136/bmjspcare-2018-001746.

43. Agarwal G, Angeles R, Pirrie M, McLeod B, Marzanek F, Parascandalo J, et al. Evaluation of a community paramedicine health promotion and lifestyle risk assessment program for older adults who live in social housing: a cluster randomized trial. CMAJ. 2018;190(21):E638-E47.

44. Agarwal G, Angeles R, Pirrie M, McLeod B, Marzanek F, Parascandalo J, et al. Reducing 9-1-1 emergency medical service calls by implementing a community paramedicine program for vulnerable older adults in public housing in Canada: a multi-site cluster randomized controlled trial. Prehosp Emerg Care. 2019;23(5):718-29.
45. Bennett K, Yuen M, Merrell M. Community paramedicine applied in a rural community. J Rural Health. 2018;34:s39-47.

46. Brydges M, Spearen C, Birze A, Tavares W. A culture in transition: paramedic experiences with community referral programs. CJEM. 2015;17(6):631-8.

47. Agarwal G, Angeles R, Pirrie M, Marzanek F, McLeod B, Parascandalo J, et al. Effectiveness of a community paramedic-led health assessment and education initiative in a seniors' residence building: the Community Health Assessment Program through Emergency Medical Services (CHAP-EMS). BMC Emerg Med. 2017;17(1):8.

48. Dainty K, Seaton M, Drennan I, Morrison L. Home visit-based community paramedicine and its potential role in improving patient-centered primary care: a grounded theory study and framework. Health Serv Res. 2018;53(5): 3455-70.

49. Jensen J, Travers A, Marshall E, Leadlay S, Carter A. Insights into the implementation and operation of a novel paramedic long-term care program. Prehosp Emerg Care. 2014;18(1):86-91.

50. Kant R, Vejar M, Parnes B, Mulder J, Daddato A, Matlock D, et al. Outcomes and provider perspectives on geriatric care by a nurse practitioner-led community paramedicine program. Geriatr Nurs. 2018;39(5):574-9.

51. Mason S, Knowles E, Freeman J, Snooks H. Safety of paramedics with extended skills. Acad Emerg Med. 2008;15(7):607-12.

52. O'Meara P, Ruest M, Martin A. Integrating a community paramedicine program with local health, aged care and social services: an observational ethnographic study. Australas J Paramed. 2015;12(5). https://ajp.paramedics. org/index.php/ajp/article/view/238. Accessed 25 Dec 2020.

53. The Paramedic Foundation. Community Paramedic 2005-2020. Available from: http://www.communityparamedic.org/Home. Accessed 25 Dec 2020.

54. Simpson P, Thomas R, Bendall J, Lord B, Lord S, Close J. 'Popping nana back into bed' - a qualitative exploration of paramedic decision making when caring for older people who have fallen. BMC Health Serv Res. 2017;17(1): 299.

55. O'Meara P, Furness S, Gleeson R. Educating paramedics for the future: a holistic approach. J Health Hum Serv Adm. 2017;40(2):219-53.

56. CSA Group Research. Health in the north; the potential for community paramedicine in remote and/or isolated indigenous communities. Canada: CSA Group; 2019.

57. CSA Group. Community paramedicine: framework for program development. Toronto: CSA Group; 2017.

58. Spelten E, Timmis J, van Vuuren J, Jackson H, Shiell A. Rural palliative care support for dying at home. Melbourne: La Trobe Rural Health School, College of Science H, and Engineering (SHE); 2019.

\section{Publisher's Note}

Springer Nature remains neutral with regard to jurisdictional claims in published maps and institutional affiliations.

Ready to submit your research? Choose BMC and benefit from

- fast, convenient online submission

- thorough peer review by experienced researchers in your field

- rapid publication on acceptance

- support for research data, including large and complex data types

- gold Open Access which fosters wider collaboration and increased citations

- maximum visibility for your research: over $100 \mathrm{M}$ website views per year

At $\mathrm{BMC}$, research is always in progress.

Learn more biomedcentral.com/submission 